\title{
Evaluation of efficacy, safety and cost of oral and parenteral iron preparations in patients with iron deficiency anemia
}

\author{
Pavan Jagdishbhai Panchal, Mira Kiranbhai Desai, Samidh P Shah, Manish N Solanki \\ Department of Pharmacology, B. J. Medical Collage, Ahmedabad-380016, India.
}

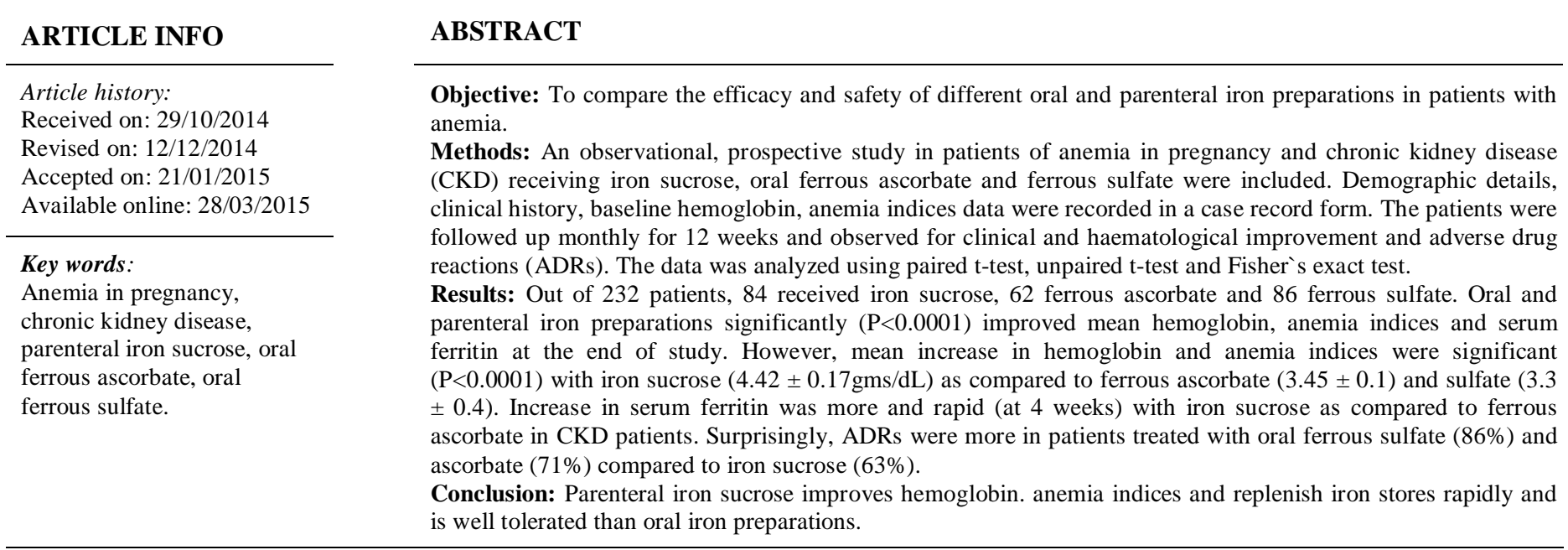

\section{INTRODUCTION}

Anemia is a sign, not a disease of dynamic process. The World Health Organization (WHO) defines anemia as hemoglobin $(\mathrm{Hb})$ below $13 \mathrm{~g} / \mathrm{dL}$ for adult males and postmenopausal women, and below $12 \mathrm{~g} / \mathrm{dL}$ for premenopausal women (WHO, 1968). According to WHO, two billion people (>30\% of the world's population) are anemic, mainly due to iron deficiency. The incidence of iron deficiency anemia (IDA) in India is $60 \%$ (urban) and 69\% (rural) population (WHO India, 2006). It is also the commonest medical disorder in pregnancy and in chronic kidney diseases (Adamson, 2011). Iron deficiency anemia manifests as a hypochromic, microcytic anemia with low hemoglobin, anemia indices (mean corpuscular volume (MCV),

\footnotetext{
* Corresponding Author

220/3, Maruti Apartment, Anand Vatika Society, Sector-22,

Gandhinagar, Gujarat, India-382022, Phone: 09978441184

E-mail: drpavanpanchal@gmail.com
}

mean corpuscular hemoglobin $(\mathrm{MCH})$ and mean corpuscular hemoglobin concentration (MCHC)) and serum ferritin (Adamson, 2011). It is commonly seen in populations with inadequate iron intake, inadequate iron absorption or increased iron requirements. These include infants, especially premature infants; children during rapid growth periods; pregnant and lactating women; and patients with chronic kidney disease who lose erythrocytes at a relatively high rate during hemodialysis (Adamson, 2011). Oral and parenteral iron preparations are used in treatment and prophylaxis of anemia (Bradley and Thomas, 2011). Oral iron preparations are used to treat mild to moderate iron deficiency anemia; whereas parenteral preparations are used to treat severe iron deficiency anemia, intolerance to oral iron preparations and malabsorption (Dipiro, 2011). Conventional oral iron preparations include ferrous sulfate, fumarate, succinate while newer preparations include ferrous ascorbate (Masters, 2013). Newer preparations such as iron sucrose and ferrous ascorbate are available \& frequently prescribed with the consideration that they are better than conventional 
preparation (Masters, 2013). However, data on the efficacy and safety of theses preparations is scare. Thus the present study was conducted to evaluate efficacy and safety of ferrous ascorbate and iron sucrose in patients with iron deficiency anemia.

\section{MATERIALS AND METHODS}

This was a continuous, prospective, observational, two centre study conducted at Institute of Kidney Diseases (IKD) and Department of Obstetrics and Gynaecology, Civil Hospital Ahmedabad (CHA), a tertiary care teaching hospital. The study was approved by Institutional Ethics Committee (IEC), CHA. Patients of anaemia in pregnancy and chronic kidney disease (CKD) of more than 16 years and either gender treated with iron sucrose, oral ferrous ascorbate and ferrous sulphate, from November 2011 to January 2013 were enrolled in the study. However, patients having anemia due to hemolysis, bone marrow depression, vitamin $\mathrm{B}_{12}$ deficiency, transfused blood or blood products in previous two months and with haemochromatosis or other iron storage disorders were excluded. Informed consent was obtained from all patients. Patients with anaemia were evaluated clinically and haematologically (haemoglobin, red blood cell indices and serum ferritin). The haematological reports were assessed by treating physician to decide treatment with oral or parenteral iron preparation. Patients with haemoglobin between 7 to $10.9(\mathrm{~g} / \mathrm{dL})$ were treated with oral ferrous salts like ferrous ascorbate $(100 \mathrm{mg} / \mathrm{day})$ and ferrous sulphate $(200 \mathrm{mg} / \mathrm{day})$ at IKD and CHA respectively. While patients with haemoglobin less than $7(\mathrm{~g} / \mathrm{dL})$ were treated with parenteral iron sucrose. Total dose of iron sucrose administered included the amount of iron needed to correct haemoglobin deficit plus to replenish iron stores. The total dose of iron was calculated by the following formula: Body weight $(\mathrm{kg}) \times 2.3 \times$ (15-patient's haemoglobin) $+500 \mathrm{mg}$ (for stores). The baseline data of the patients were recorded in pretested case record form. Each patient was followed up every month and assessed for clinical and haematological parameters and adverse drug reactions (ADRs) for three months. Hemoglobin, anemia indices and serum ferritin (in CKD patients) were measured at baseline and at the end of each month for subsequent three months. The data was recorded in Microsoft Excel Worksheet and analysed by Fisher's exact test and paired ' $t$ ' test and unpaired ' $t$ ' test with the help of GraphPad Prism 5.0 software. $\mathrm{P}<0.05$ considered as statistically significant.

\section{RESULT}

\section{Baseline Characteristics}

Out of 232 patients, 67 were men and 165 were women. Of these, 84 were treated with parenteral iron sucrose, 62 with ferrous ascorbate and 86 with ferrous sulfate. The mean age of patients received ferrous ascorbate and iron sucrose was $42.6 \pm$ 18.3 years, while those treated with ferrous sulfate was $23.6 \pm 5.8$ (pregnant patients). The most frequent presenting complaints were fatigue followed by breathlessness and most common sign was mild to severe pallor of tongue, nail and conjunctiva (Table 1).
While mean baseline hemoglobin (gms \%) was $7.7 \pm 0.5$ in iron sucrose treated patients as compared to $9 \pm 0.3$ and $8.9 \pm 0.4$ with ferrous ascorbate and ferrous sulfate respectively (Table 1). Mean baseline serum ferritin $(\mathrm{ng} / \mathrm{ml})$ was low $(30 \pm 6.1)$ in iron sucrose treated patients as compared to $41.7 \pm 6.8$ ferrous ascorbate treated group (Table 1). Baseline anemia indices were comparable in all three iron preparations treated patients (Table 1).

\section{Outcome of iron therapy \\ Clinical assessment}

A significant improvement $(\mathrm{p}<0.0001)$ in fatigue and breathlessness was observed in patients treated with oral and parenteral iron patients at first follow up. All patients were symptom free at the end of second follow up in all three groups (Table 2).

\section{Hematological assessment}

A significant $(\mathrm{p}<0.0001)$ improvement in mean hemoglobin, anemia indices (MCV, $\mathrm{MCH}$ and $\mathrm{MCHC}$ ) and serum ferritin was observed in patients treated with ferrous ascorbate, ferrous sulfate and iron sucrose at 12 weeks (Table 3 ).

\section{Comparison between different treatment groups \\ Comparison between ferrous ascorbate and ferrous sulfate}

The increase in mean hemoglobin was significant $(p<0.0001)$ with ferrous ascorbate treated patients at the end of treatment as compared to ferrous sulfate. While there was a significant $(\mathrm{p}<0.005)$ improvement in mean $\mathrm{MCH}$ with ferrous sulfate group as compared to ferrous ascorbate group (Table 4)

\section{Comparison between iron sucrose and ferrous ascorbate}

There was a significant $(\mathrm{p}<0.0001)$ increase in mean hemoglobin and anemia indices ( $\mathrm{MCV}, \mathrm{MCH}$ and $\mathrm{MCHC}$ ) in patients treated with iron sucrose as compared to ferrous ascorbate at end of treatment(12 weeks). Secondly, mean increase in serum ferritin was significant $(p<0.0001)$ and rapid with iron sucrose at 4 weeks as compared to ferrous ascorbate group. While there was slow, steady and significant $(\mathrm{p}<0.005)$ increase in serum ferritin at 8 and 12 weeks with ferrous ascorbate treated patients as compared to iron sucrose (Table 5 and figure 1).

\section{Adverse Drug Reactions (ADRs)}

A total of 171 ADRs were observed in 232 patients during the study period. The most common ADR was nausea (54) followed by heart burn (44). Out of 171 ADRs, 44 (25.7\%) were reported from ferrous ascorbate treated group, $74(43.2 \%)$ from ferrous sulfate and 53 (30.9\%) from iron sucrose group (Table 6). ADRs were categorized as mild, moderate and severe based on modified Hartwig and Siegel scale (Table 6). However, none of the ADR required withdrawal of causal drug. Causality assessment showed that majority of ADRs (171) were categorized as possible in nature by WHO-UMC scale and probable by Naranjo`s scale (Table 6). 


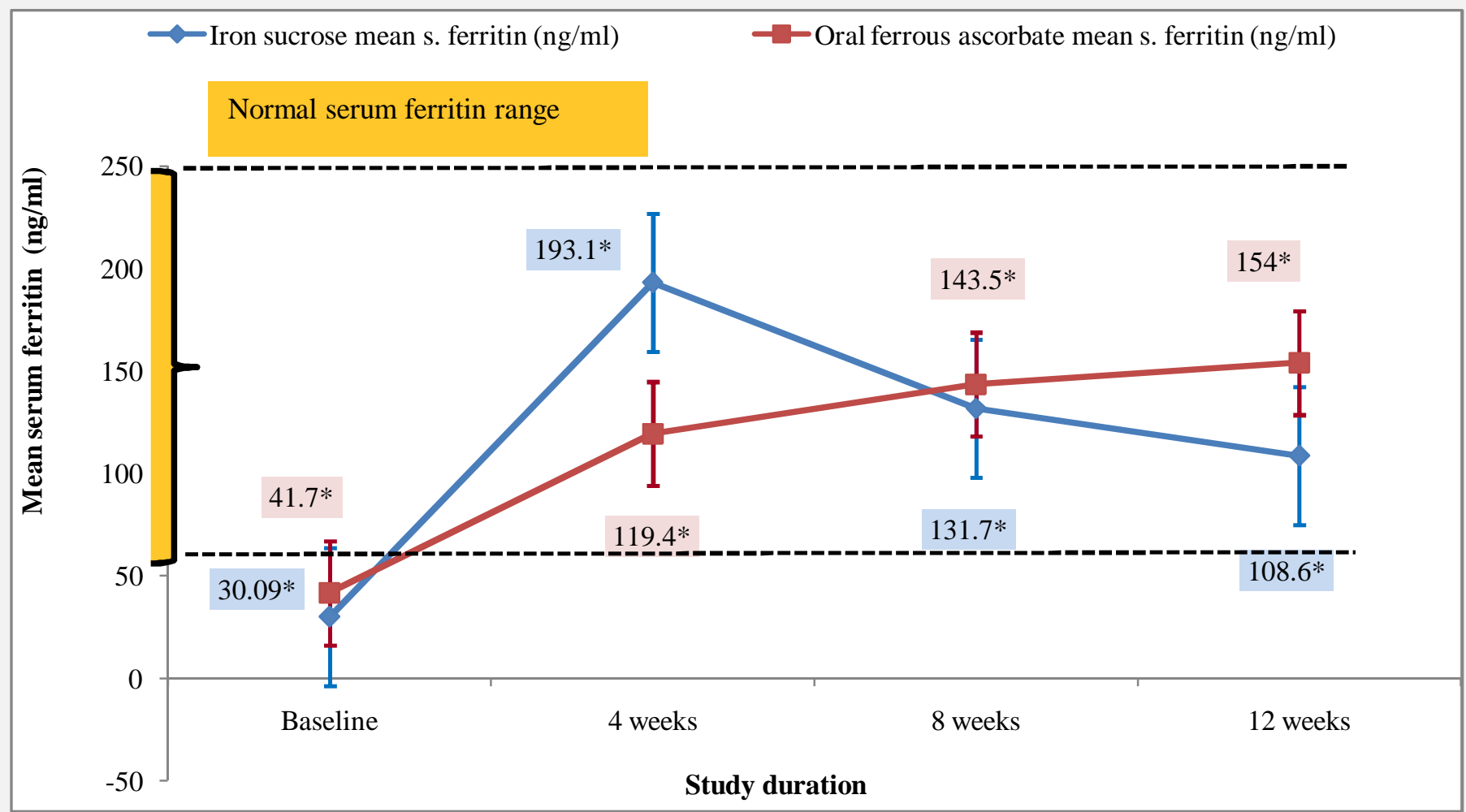

Fig. 1: Comparison of mean serum ferritin in patients treated with ferrous ascorbate and iron sucrose $(\mathrm{n}=99)$. $* \mathrm{P}<0.0001$ as compared to baseline $($ Paired student's't' test), Normal serum ferritin level for adult - 30 to $300(\mathrm{ng} / \mathrm{ml})$.

Table 1: Baseline characteristics of the patients with anemia $(n=232)$.

\begin{tabular}{|c|c|c|c|}
\hline \multirow[t]{2}{*}{ Parameter } & \multicolumn{3}{|c|}{ Treatment groups } \\
\hline & $\begin{array}{l}\text { Ferrous ascorbate } \\
\text { (CKD patients) }\end{array}$ & $\begin{array}{c}\text { Ferrous sulfate } \\
\text { (Pregnant patients) }\end{array}$ & $\begin{array}{c}\text { Iron sucrose } \\
(\mathrm{CKD}+\text { Pregnant patients) } \\
\end{array}$ \\
\hline Number of patients & 62 & 86 & 84 \\
\hline Mean age (Years) & $53.4 \pm 18.3$ & $23.6 \pm 5.8$ & $54.8 \pm 16.7$ \\
\hline \multicolumn{4}{|l|}{ Gender } \\
\hline Men & 41 & 00 & 26 \\
\hline Women & 21 & 86 & 58 \\
\hline \multicolumn{4}{|l|}{ Clinical symptoms } \\
\hline Fatigue (\%) & $62(100)$ & $86(100)$ & $84(100)$ \\
\hline Breathlessness (\%) & $9(14.5)$ & $9(10.5)$ & $78(92.2)$ \\
\hline \multicolumn{4}{|c|}{ Clinical signs (Severity of pallor of tongue, conjunctiva and nail) } \\
\hline Mild (\%) & $54(87)$ & $73(84.8)$ & $46(54.7)$ \\
\hline Moderate (\%) & $8(13)$ & $13(15.2)$ & $7(8.3)$ \\
\hline Severe $(\%)$ & $0(0)$ & $0(0)$ & $31(36.6)$ \\
\hline \multicolumn{4}{|l|}{ Laboratory parameters } \\
\hline Mean $\mathrm{Hb}(\mathrm{gms} \%)$ & $9 \pm 0.3$ & $8.9 \pm 0.4$ & $7.7 \pm 0.5$ \\
\hline Mean $\operatorname{MCV}(\mu \mathrm{m} 3)$ & $65.5 \pm 7.6$ & $64.6 \pm 3.2$ & $61.7 \pm 3.5$ \\
\hline Mean MCH (pg/cell) & $27.6 \pm 0.8$ & $25.2 \pm 0.8$ & $25.7 \pm 1.2$ \\
\hline Mean MCHC (g/dl) & $31.5 \pm 5.8$ & $30.5 \pm 6.1$ & $29.1 \pm 1.8$ \\
\hline Mean Serum Ferritin (ng/ml) & $41.7 \pm 6.8$ & - & $30 \pm 6.1$ \\
\hline
\end{tabular}

Table 2: Comparison of clinical symptoms of patients at different time interval $(\mathrm{n}=232)$. [Values are absolute count $(\%)$ ]

\begin{tabular}{cccccc}
\hline Study groups & Symptoms & Baseline & $\mathbf{1}^{\text {st }} \mathbf{F U}$ & $\mathbf{2}^{\text {nd }} \mathbf{F U}$ & $\mathbf{3}^{\text {rd }} \mathbf{F U}$ \\
\hline \multirow{2}{*}{ Ferrous ascorbate (n=62) } & Fatigue (\%) & $62(100)$ & $6(9.67)^{\#}$ & $0(0)^{\#}$ & $0(0)^{\#}$ \\
& Breathlessness (\%) & $9(14.5)$ & $0(0)^{\#}$ & $0(0)^{\#}$ & $0(0)^{\#}$ \\
\hline \multirow{2}{*}{ Ferrous sulphate (n=86) } & Fatigue (\%) & $86(100)$ & $11(12.7)^{\#}$ & $0(0)^{\#}$ & $0(0)^{\#}$ \\
& Breathlessness (\%) & $9(10.5)$ & $0(0)^{\#}$ & $0(0)^{\#}$ & $0(0)^{\#}$ \\
\hline \multirow{2}{*}{ Iron sucrose (n=84) } & Fatigue (\%) & $84(100)$ & $9(10.7)^{\#}$ & $0(0)^{\#}$ & $0(0)^{\#}$ \\
& Breathlessness (\%) & $78(92.2)$ & $0(0)^{\#}$ & $0(0)^{\#}$ & $0(0)^{\#}$ \\
\hline
\end{tabular}

${ }^{\#} \mathrm{P}<0.0001$ as compared to baseline (Fisher's exact text). $\mathrm{FU}=$ follow up. 
Table 3: Comparison of laboratory parameters of patients at different time interval $(n=232)$ [Values are mean \pm SEM]

\begin{tabular}{|c|c|c|c|c|}
\hline \multirow{2}{*}{$\begin{array}{c}\text { Visit/ } \\
\text { Follow up } \\
\text { (FU) }\end{array}$} & \multicolumn{4}{|c|}{ Treatment groups } \\
\hline & Laboratory parameters & $\begin{array}{c}\text { Ferrous } \\
\text { ascorbate }\end{array}$ & $\begin{array}{l}\text { Ferrous } \\
\text { sulphate }\end{array}$ & Iron sucrose \\
\hline \multirow{5}{*}{ Baseline } & $\mathrm{Hb}$ (gms \%) & $9 \pm 0.3$ & $8.9 \pm 0.4$ & $7.7 \pm 0.5$ \\
\hline & $\operatorname{MCV}\left(\mu \mathrm{m}^{3}\right)$ & $65.5 \pm 7.6$ & $64.6 \pm 3.2$ & $61.7 \pm 3.5$ \\
\hline & MCH (pg/cell) & $27.6 \pm 0.8$ & $25.2 \pm 0.8$ & $25.7 \pm 1.2$ \\
\hline & $\mathrm{MCHC}(\mathrm{g} / \mathrm{dl})$ & $31.5 \pm 5.8$ & $30.5 \pm 6.1$ & $29.1 \pm 1.8$ \\
\hline & Serum Ferritin $(\mathrm{ng} / \mathrm{ml})$ & $41.7 \pm 6.8$ & - & $30 \pm 6.1$ \\
\hline \multirow{5}{*}{$\mathbf{1}^{\text {st }} \mathbf{F U}$} & $\mathrm{Hb}(\mathrm{gms} \%)$ & $10.8 \pm 0.6^{*}$ & $10.2 \pm 0.2 *$ & $9.9 \pm 0.8^{*}$ \\
\hline & $\operatorname{MCV}\left(\mu \mathrm{m}^{3}\right)$ & $67.8 \pm 7.6^{*}$ & $66.8 \pm 4.2 *$ & $66.3 \pm 2.7 *$ \\
\hline & $\mathrm{MCH}(\mathrm{pg} /$ cell $)$ & $29.3 \pm 1.2 *$ & $28.3 \pm 4.6^{*}$ & $27.8 \pm 1.4^{*}$ \\
\hline & $\mathrm{MCHC}(\mathrm{g} / \mathrm{dl})$ & $33.1 \pm 6.4^{*}$ & $32.5 \pm 7.2 *$ & $30.9 \pm 1.4^{*}$ \\
\hline & Serum Ferritin (ng/ml) & $119.4 \pm 27 *$ & - & $193.1 \pm 34^{*}$ \\
\hline \multirow{5}{*}{$2^{\text {nd }} \mathbf{F U}$} & $\mathrm{Hb}(\mathrm{gms} \%)$ & $11.9 \pm 0.6^{*}$ & $11.2 \pm 0.1^{*}$ & $11.5 \pm 0.7 *$ \\
\hline & $\operatorname{MCV}\left(\mu \mathrm{m}^{3}\right)$ & $69.3 \pm 7.5^{*}$ & $68.5 \pm 8.1^{*}$ & $69.2 \pm 1.7 *$ \\
\hline & $\mathrm{MCH}(\mathrm{pg} /$ cell $)$ & $30.2 \pm 1.1 *$ & $29.4 \pm 5.2 *$ & $29.2 \pm 1.1^{*}$ \\
\hline & $\mathrm{MCHC}(\mathrm{g} / \mathrm{dl})$ & $33.8 \pm 6.7 *$ & $33.2 \pm 8.3^{*}$ & $32 \pm 0.7 *$ \\
\hline & Serum Ferritin (ng/ml) & $142.8 \pm 28^{*}$ & - & $131.7 \pm 26^{*}$ \\
\hline \multirow{5}{*}{$3^{\text {rd }} \mathbf{F U}$} & $\mathrm{Hb}(\mathrm{gms} \%)$ & $12.4 \pm 0.5^{*}$ & $12.2 \pm 0.7 *$ & $12.1 \pm 0.6^{*}$ \\
\hline & $\operatorname{MCV}\left(\mu \mathrm{m}^{3}\right)$ & $69.9 \pm 7.3^{*}$ & $69.4 \pm 5.2 *$ & $70.1 \pm 1.4^{*}$ \\
\hline & $\mathrm{MCH}(\mathrm{pg} /$ cell $)$ & $30.8 \pm 1^{*}$ & $29.9 \pm 2.3^{*}$ & $29.9 \pm 0.8^{*}$ \\
\hline & $\mathrm{MCHC}(\mathrm{g} / \mathrm{dl})$ & $34.1 \pm 6.8^{*}$ & $33.7 \pm 1.5^{*}$ & $32.3 \pm 0.5^{*}$ \\
\hline & Serum Ferritin $(\mathrm{ng} / \mathrm{ml})$ & $154 \pm 31 *$ & - & $108.6 \pm 36^{*}$ \\
\hline
\end{tabular}

*P<0.0001 as compared to baseline (Paired student`s ' $\mathrm{t}$ ' test), Hb- Hemoglobin. MCV - Mean corpuscle volume. MCH - Mean corpuscle hemoglobin. MCHC Mean corpuscle hemoglobin concentration

Table 4: Comparison of difference in mean value of laboratory parameters of patients treated with oral iron preparations ( $\mathrm{n}=148)$ [Values are mean \pm SEM].

\begin{tabular}{|c|c|c|c|c|c|c|c|c|}
\hline \multirow{2}{*}{ Parameters } & \multicolumn{2}{|c|}{$\begin{array}{l}\text { Mean difference at } \\
\text { first follow up } \\
\text { (4 weeks) }\end{array}$} & \multicolumn{2}{|c|}{$\begin{array}{l}\text { Mean difference at second } \\
\text { follow up } \\
\text { (8 weeks) }\end{array}$} & \multicolumn{2}{|c|}{$\begin{array}{c}\text { Mean difference at third follow } \\
\text { up } \\
\text { (12 weeks) }\end{array}$} & \multicolumn{2}{|c|}{$\begin{array}{l}\text { Total mean difference } \\
\text { (12 weeks) }\end{array}$} \\
\hline & $\begin{array}{c}\text { Ferrous } \\
\text { ascorbate } \\
(\mathbf{n}=62) \\
\end{array}$ & $\begin{array}{l}\text { Ferrous } \\
\text { sulfate } \\
(\mathbf{n}=86) \\
\end{array}$ & $\begin{array}{c}\text { Ferrous } \\
\text { ascorbate } \\
(\mathbf{n}=62) \\
\end{array}$ & $\begin{array}{l}\text { Ferrous } \\
\text { sulfate } \\
(\mathbf{n}=86) \\
\end{array}$ & $\begin{array}{c}\text { Ferrous } \\
\text { ascorbate } \\
(\mathbf{n}=62)\end{array}$ & $\begin{array}{l}\text { Ferrous } \\
\text { sulfate } \\
(\mathrm{n}=86) \\
\end{array}$ & $\begin{array}{c}\text { Ferrous } \\
\text { ascorbate } \\
(\mathbf{n}=62) \\
\end{array}$ & $\begin{array}{l}\text { Ferrous } \\
\text { sulfate } \\
(\mathbf{n}=86)\end{array}$ \\
\hline $\mathrm{Hb}(\mathrm{gms} \%)$ & $1.8 \pm 0.1 *$ & $1.3 \pm 0.2$ & $1 \pm 0.12$ & $1 \pm 0.1$ & $0.47 \pm 0.06$ & $1 \pm 0.1 * *$ & $3.45 \pm 0.1 *$ & $3.3 \pm 0.4$ \\
\hline $\operatorname{MCV}\left(\mu \mathrm{m}^{3}\right)$ & $2.3 \pm 0.16^{*}$ & $1.2 \pm 1$ & $1.5 \pm 028$ & $1.7 \pm 3.9 * *$ & $0.64 \pm 0.15^{*}$ & $0.9 \pm 2.9 * *$ & $4.3 \pm 0.25$ & $4.8 \pm 2$ \\
\hline MCH (pg/cell) & $1.6 \pm 0.13$ & $3.1 \pm 3.8 * *$ & $0.87 \pm 0.13$ & $1.1 \pm 0.6^{* *}$ & $0.6 \pm 0.12$ & $0.5 \pm 2.9$ & $3.15 \pm 0.9$ & $4.7 \pm 1.5 * *$ \\
\hline $\operatorname{MCHC}(\mathrm{g} / \mathrm{dl})$ & $1.6 \pm 0.14$ & $2 \pm 1.1$ & $0.64 \pm 0.1$ & $0.7 \pm 1.6$ & $0.33 \pm 0.08$ & $0.5 \pm 6.8$ & $2.58 \pm 0.21$ & $3.2 \pm 4.6$ \\
\hline
\end{tabular}

* $\mathrm{P}<0.0001$ as compared to ferrous sulfate treated group (Unpaired student's ' $\mathrm{t}$ ' test), **p<0.005 as compared to ascorbate treated group (Unpaired student's' $\mathrm{t}$ ' test). Oral ferrous ascorbate tr ineated patients chronic kidney disease $(\mathrm{n}=62)$ and oral ferrous sulfate treated patients in pregnancy ( $\mathrm{n}=86)$. Hb- Hemoglobin. MCV - Mean corpuscle volume. MCH - Mean corpuscle hemoglobin. MCHC - Mean corpuscle hemoglobin concentration.

Table 5: Comparison of difference in mean value of laboratory parameters of patients treated with oral iron and parenteral preparations ( $\mathrm{n}=144$ ) [Values are mean \pm SEM].

\begin{tabular}{|c|c|c|c|c|c|c|c|c|}
\hline \multirow{2}{*}{ Parameters } & \multicolumn{2}{|c|}{$\begin{array}{l}\text { Mean difference at } \\
\text { first follow up } \\
\text { (4 weeks) }\end{array}$} & \multicolumn{2}{|c|}{$\begin{array}{c}\text { Mean difference at second } \\
\text { follow up } \\
\text { (8 weeks) }\end{array}$} & \multicolumn{2}{|c|}{$\begin{array}{c}\text { Mean difference at third follow } \\
\text { up } \\
\text { (12 weeks) }\end{array}$} & \multicolumn{2}{|c|}{$\begin{array}{l}\text { Total mean difference } \\
\text { (12 weeks) }\end{array}$} \\
\hline & $\begin{array}{l}\text { Iron sucrose } \\
\quad(n=84)\end{array}$ & $\begin{array}{c}\text { Ferrous } \\
\text { ascorbate } \\
(\mathbf{n}=62)\end{array}$ & $\begin{array}{l}\text { Iron sucrose } \\
\quad(n=84)\end{array}$ & $\begin{array}{c}\text { Ferrous } \\
\text { ascorbate } \\
(\mathbf{n}=62)\end{array}$ & $\begin{array}{c}\text { Iron sucrose } \\
(\mathbf{n}=\mathbf{8 4})\end{array}$ & $\begin{array}{c}\begin{array}{c}\text { Ferrous } \\
\text { ascorbate } \\
(\mathbf{n}=62)\end{array} \\
\end{array}$ & $\begin{array}{l}\text { Iron sucrose } \\
\quad(n=84)\end{array}$ & $\begin{array}{c}\text { Ferrous } \\
\text { ascorbate } \\
(\mathbf{n}=62)\end{array}$ \\
\hline $\mathrm{Hb}(\mathrm{gms} \%)$ & $2.23 \pm 0.13 *$ & $1.8 \pm 0.1$ & $1.56 \pm 0.5^{*}$ & $1 \pm 0.12$ & $0.62 \pm 0.1 *$ & $0.47 \pm 0.06$ & $4.42 \pm 0.17 *$ & $3.45 \pm 0.1$ \\
\hline $\operatorname{MCV}\left(\mu \mathrm{m}^{3}\right)$ & $4.5 \pm 0.44 *$ & $2.3 \pm 0.16$ & $2.8 \pm 0.4^{*}$ & $1.5 \pm 028$ & $0.97 \pm 0.2 *$ & $0.64 \pm 0.15$ & $8.4 \pm 0.84^{*}$ & $4.3 \pm 0.25$ \\
\hline $\mathrm{MCH}$ (pg/cell) & $2.12 \pm 0.1 *$ & $1.6 \pm 0.13$ & $1.2 \pm 0.7 *$ & $0.87 \pm 0.13$ & $0.68 \pm 0.22$ & $0.6 \pm 0.12$ & $4.17 \pm 0.25^{*}$ & $3.15 \pm 0.9$ \\
\hline $\mathrm{MCHC}(\mathrm{g} / \mathrm{dl})$ & $1.82 \pm 0.22$ & $1.6 \pm 0.14$ & $1.09 \pm 0.2 *$ & $0.64 \pm 0.1$ & $0.25 \pm 0.15$ & $0.33 \pm 0.08$ & $3.17 \pm 0.45^{*}$ & $2.58 \pm 0.21$ \\
\hline $\begin{array}{l}\text { Serum ferritin } \\
(\mathrm{ng} / \mathrm{ml})\end{array}$ & $163 \pm 8.6^{*}$ & $77.7 \pm 5.2$ & $-61 \pm 6.6$ & $23.8 \pm 2.6^{* *}$ & $-23 \pm 7.2$ & $9.8 \pm 4.2^{*}$ & $78.57 \pm 9.2 *$ & $12.3 \pm 5.6$ \\
\hline
\end{tabular}

* $\mathrm{P}<0.0001$ as compared to ferrous ascorbate (Unpaired student' $\mathrm{s}$ 't' test), $* * \mathrm{P}<0.005$ as compared to iron sucrose (Unpaired student's ' $\mathrm{t}$ ' test). Parenteral iron sucrose treated patients in chronic kidney disease and in pregnancy $(n=84)$ and oral ferrous ascorbate treated group in chronic kidney disease patients $(n=62)$. HbHemoglobin. MCV - Mean corpuscle volume. MCH - Mean corpuscle hemoglobin. MCHC - Mean corpuscle hemoglobin concentration. 
Table 6: Details of adverse drug reactions (ADRs) observed among patients treated with iron preparations in the study $(\mathrm{n}=232)$

\begin{tabular}{|c|c|c|c|c|c|}
\hline & ADRs & Treatment group (s) & $\begin{array}{c}\text { Number } \\
(\%)\end{array}$ & $\begin{array}{c}\text { WHO-UMC } \\
\text { Causality scale }\end{array}$ & $\begin{array}{l}\text { Severity of ADRs } \\
\text { (Hartwig and } \\
\text { Siegel scale) }\end{array}$ \\
\hline \multirow{6}{*}{ 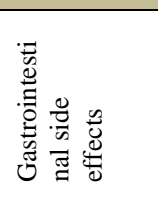 } & Nausea & Iron sucrose, ferrous ascorbate and ferrous sulfate & $54(31.5)$ & Possible & Mild \\
\hline & Heart burn & Iron sucrose, ferrous ascorbate and ferrous sulfate & $44(25.7)$ & Possible & Mild \\
\hline & Constipation & Ferrous ascorbate and ferrous sulfate & $23(13.4)$ & Possible & Mild \\
\hline & Epigastric distress & Iron sucrose, ferrous ascorbate and ferrous sulfate & $16(9.3)$ & Possible & Mild \\
\hline & Vomiting & Iron sucrose, ferrous ascorbate and ferrous sulfate & $11(6.4)$ & Possible & Mild \\
\hline & Metallic taste & Ferrous ascorbate and ferrous sulfate & $7(4)$ & Possible & Mild \\
\hline \multicolumn{2}{|l|}{ Rashes } & Iron sucrose & $6(3.5)$ & Possible & Mild \\
\hline \multicolumn{2}{|l|}{ Hypotension } & Iron sucrose & $2(1.1)$ & Possible & Mild \\
\hline \multicolumn{2}{|l|}{ Headache } & Ferrous ascorbate and ferrous sulfate & $4(2.3)$ & Possible & Mild \\
\hline \multicolumn{2}{|l|}{ Arthralgia } & Iron sucrose & $2(1.1)$ & Possible & Mild \\
\hline \multicolumn{2}{|l|}{ Bodyache } & Iron sucrose & $4(2.3)$ & Possible & Mild \\
\hline \multicolumn{2}{|l|}{ Malaise } & Iron sucrose & $4(2.3)$ & Possible & Mild \\
\hline \multicolumn{2}{|l|}{ Total } & - & $171(100)$ & - & \\
\hline
\end{tabular}

\section{Total cost of drug treatment of anemia}

The cost of drug treatment of anemia has been calculated in terms of direct and indirect cost in terms of rupees spent per patient per month.

\section{Direct cost}

This refers to cost incurred to patient for purchase of drugs plus laboratory investigations plus the amount spent towards transportation to hospital. The mean direct cost of therapy in iron sucrose treat patients was Rs. 1121.6 [95\% CI (1068.5, 1178.9)], Rs. 569.39 [95\% CI $(557.4,581.38)]$ with ferrous ascorbate and Rs. 113.3 [95\% CI $(102.4,125.8)]$ with ferrous sulfate.

\section{Indirect cost}

This refers to the loss of daily wages of the patient and accompanying person. The mean indirect cost of therapy in iron sucrose group was Rs. 519.7 [95\% CI (464.1, 575.2)]. While in ferrous ascorbate treated group was Rs. 700.3 [95\% CI (645.8, 744.4)] and ferrous sulfate group was Rs. 295.7 [95\% CI (271.9, 323.5)].

\section{Total cost}

Mean total cost of therapy in patients treated with iron sucrose was Rs. 1641.3 [95\% CI (1532.6, 1754.1)], in ferrous ascorbate group was Rs. 1269.6 [95\% CI $(1203.2,1325.8)]$ and in ferrous sulfate group was Rs. 409.7 [95\% CI (378.4, 442.7)].

\section{DISCUSSION}

Iron deficiency anemia (IDA) is one of the most prevalent nutritional deficiencies in the world and $12^{\text {th }}$ most important risk factor for all mortality globally (Mason et al., 2005). It can be effectively treated and prevented by using nutritional diet, different oral and parenteral iron preparations (Miyashita et al., 2011). Conventional oral iron preparations frequently cause side effects, non compliance is common and therapy had to be given for long time in case of severe iron deficiency (Miyashita et al., 2011). Moreover, absorption of oral iron preparations from gastrointestina 1 tract and red blood cells production are influenced by comorbid conditions such as renal disease and pregnancy (Miyashita et al., 2011). On the other hand, among parenteral iron preparation iron sucrose is considered to be better tolerated with few side effects than iron dextran (Faich and Strobos, 1999). It has been approved by FDA for the treatment of iron deficiency in patients with chronic kidney disease (Faich and Strobos, 1999). It had also been widely prescribed to treat iron deficiency in pregnancy (Faich and Strobos, 1999). Ferrous ascorbate, a novel oral iron preparation, claims to enhance the process of iron absorption in gastrointestinal tract (Megha, 2012)

Our study showed the treatment outcomes of total 232 patients treated with oral ferrous ascorbate, ferrous sulfate and parenteral iron sucrose for three months. In our study we could not compare iron sucrose with other convention parenteral iron preparations, owing to they were not availability in the market. After 3 months of follow up, all 232 patients remained on treatment with no deaths or drop outs. Three months treatment showed that all patients had normalized hematological parameters (hemoglobin, anemia indices and serum ferritin) with clinical improvement, giving 100\% treatment success with all three iron preparations.

Our study showed that the most common age group was $16-30(37.9 \%)$ years followed by $46-60(21.9 \%)$ years. The mean age of patients in our study was higher (42.6 years) as compared to studies done at Jordan (31.1 years) and lower than at Turkey (44.5 years) and Romania (52.2 years) (Khaldoun et al., 2011). There were more women $(71.2 \%)$ than men $(28.8 \%)$ in our study probably due to including pregnant patients with anemia in our study. This also indicates high prevalence of iron deficiency in women. However, national data shows that $69 \%$ of the total iron deficiency anemia patients are young women, which is lower than our finding (75.7\% young women). In our study, we observed fatigue and breathlessness were most common presenting symptoms. This can be because of decrease oxygenation of skeletal muscle as result of low oxygen carrying capacity in anemia patients (Miyashita et al., 2011). Pallor of tongue, nail and conjunctiva was also seen in the patients and its severity was related to hemoglobin concentration. Similar findings had been reported in studies conducted at Jordan, USA and Turkey (Tokars, 2010). Different hematological parameters like hemoglobin, 
anemic indices ( $\mathrm{MCV}, \mathrm{MCH}$ and $\mathrm{MCHC}$ ) and biochemical parameter like serum ferritin was also used to diagnose the anemia, determine its severity and low iron store. The difference in baseline value of laboratory parameters is because of difference in severity of anemia in patients treated with oral and parenteral iron preparations. Similar difference in baseline values had been observed at UK and USA (Stoves, 2001). The revised guideline from National Kidney Foundation-Dialysis Outcomes Quality Initiative (NKF-DOQI) (2006) recommend that a CKD patient's hemoglobin $(\mathrm{Hb})$ be checked annually regardless of the cause or state of the disease. In addition, the guideline also recommends iron supplementation in order to maintain adequate anemia indices, serum ferritin levels and hemoglobin (11-12 g/dL) levels (Mircescu, 2006).

Oral and parenteral iron treatment resulted into a significant progressive improvement in fatigue and breathlessness at each follow up and all patients were symptom free at the end of 3 months treatment with oral and parenteral iron preparations. Our observations are similar to the studies conducted at Jordan and Turkey (Suheyl et al., 2009). The treatment with oral and parenteral iron preparations improves availability of elemental iron for erythropoesis and that improves signs and symptoms of anemia (Rang at al., 2011). A parallel improvement in hematological parameters was noted in our study. The baseline characteristics of study groups were not comparable because of difference in underlying populations and severity of anemia. It was observed that there was more and significant increase in hemoglobin in patients treated with ferrous ascorbate as compare to ferrous sulfate. Probably, this may be due to ferrous ascorbate being a synthetic iron molecule with ascorbate a reducing agent, reduces iron in highly soluble ferrous form and enhances its absorption from gastrointestinal tract. ${ }^{(12,13)}$ Moreover, patients with severe anemia treated with iron sucrose had more significant increase in mean hemoglobin and anemia indices ( $\mathrm{MCV}, \mathrm{MCH}$ and $\mathrm{MCHC}$ ) as compared to ferrous ascorbate. Iron sucrose when administered is taken up by reticuloendothelial cell in liver, spleen and bone marrow and gets hydrolysed into sucrose and iron. Sucrose is eliminated by kidney and iron is quickly available for erythropoiesis to erythroblast progenitor in bone marrow (Suheyl et al., 2009). Similarly, iron sucrose also resulted into a rapid and significant) increase with serum ferritin level as compare to ferrous ascorbate. Similar observation had observed at USA and Turkey (Tokars, 2010)

However, in our study we could not compare efficacy and safety of iron sucrose with other parenteral iron preparations like iron dextran and iron sorbitol citrate, as they were not available and no more prescribed by the clinician. Thus we had compared iron sucrose with historical control group of conventional iron preparation. This shows that there was more and significant increase in mean hemoglobin and anemia indices (MCV and $\mathrm{MCH}$ ) in iron sucrose treated patients as compared to iron sorbitol citrate treated patients. This is because nearly 33-35\% of iron sorbitol citrate is excreted immediately and also its release from the reticuloendothelial system is much slower as compared to iron sucrose (Stoves et al., 2001). Similar observation has been documented in study conducted by Wali et al., 2002 (Khaldoun et al., 2011). Similarly, iron transportation to reticuloendothelial cells and its conversion to unstable iron stores very gradual with iron dextran (Bradley and Thomas, 2011). Further, iron sucrose administration resulted into rapid and significant increase with serum ferritin level above minimal require level. Similar observations had been documented at Tokars ML, 2010 and Suheyl Asma et al., 2009.

All three iron preparations were well tolerated and no serious adverse event was reported. The most common ADRs reported were heart burn (31.5\%), nausea $(25.7 \%)$ and constipation (13.4\%) and mild in nature. This is because of iron sucrose is complex of ferric hydroxide sucrose, which is highly stabilize and has low propensity to cause anaphylactic reactions with iron sucrose. ${ }^{(15)}$ In our study, patients treated with iron sucrose had 30.9\% ADRs as compared to 25.7\% ADRs with ferrous ascorbate. Similar observations had been reported by Suheyl Asma et al., 2009. A comparison between two ferrous salts showed that ADRs with ferrous ascorbate were low (25.7\%) as compared to ferrous sulfate $(43.2 \%)$. This is due to more free elemental iron presents in ferrous sulfate tract which increases gastro-intestinal irritation. Ferrous ascorbate provide better stability of iron-ascorbate complex in gastro-intestinal tract which prevent dissociation of iron from ascorbate (Kiran et al., 2010). In addition, ascorbate prevent oxidation ferrous of to ferric form which enhances its absorption from upper intestine (Megha, 2012). While evaluating safety parameter between iron sucrose treated patient and historical control group, iron sucrose was well tolerated and there no serious adverse event was observed. ADRs were more in patients treated with iron sorbitol citrate (103.3\%) and iron dextran $(155.1 \%)$ as compared to iron sucrose (30.9\%). Most common ADRs documented with iron sorbitol citrate were burning pain (11) and blackening (7) at site of injection. Iron sorbitol produces more ADRs owing to low molecular weight and has high transferring saturation capacity; it cannot be given as intravenous infusion and mainly used as intramuscularly. Similar observations were noted in study done by Wali et al, 2002 (Khaldoun et al., 2011). With iron dextran produced anaphylactic reaction in one patient and led to premature discontinuation of 11 patients from study due to ADRs. Iron dextran frequently produces acute and delayed type of hypersensitivity reactions and the incidence of severe anaphylactic reactions during iron dextran therapy is $0.6-0.7 \%$ (Bradley and Thomas, 2011). Iron sucrose has low propensity for anaphylactic reaction as compared to iron dextran (Rang et al., 2011)

The average cost incurred to patient treated with iron sucrose was highest followed by ferrous ascorbate and ferrous sulfate. The cost of therapy per patient per month with iron sucrose was ` $1,641.3$. While with ferrous ascorbate, it was `1, 269 and 409.7 with ferrous sulfate. The average direct cost incurred to the patients was more with iron sucrose as compared to ferrous ascorbate and ferrous sulfate. Within each iron preparation treated group, the cost incurred to the patients was more in patients treated 
with iron sucrose. Similar observations have been made at Turkey, where in the average cost of treatment with iron sucrose was higher (\$ 143) as compare to oral iron therapy (\$ 30) (Suheyl et al., 2009). Cost of treatment incurred by patients per month is three times higher with ferrous ascorbate as compared to ferrous sulfate.

\section{CONCLUSION}

Intravenous iron sucrose causes faster replenishment of iron store and more improvement in clinical symptomatogy and laboratory parameters with better safety profile. There is significant difference found between ferrous ascorbate and ferrous sulfate. However, ferrous ascorbate was better tolerated and more expensive as compared to ferrous sulfate.

\section{REFERENCES}

World Health Organization. Nutritional Anaemias: Report of a WHO scientific group. Tech. Rep. 1968. 405: 5-37.

WHO India; Core Programme Clusters; Family and Community Health; [ONLINE] Available on: www.whoindia.org/en/Section6/ Section324 [Accessed 13 May 2006].

Good Clinical Practice Recommendations for Iron Deficiency Anemia in Pregnancy (IDA) in Pregnancy in India. The Journal of Obstetrics and Gynecology of India; [ONLINE] Available on: http://www.ncbi.nlm.nih.gov/pmc/articles/PMC3257335/ [Accessed 08 December 2011].

Adamson JW. 2011. Iron Deficiency and Other Hypoproliferative Anemias. Harrison's Principles of Internal Medicine. 18th International Edition: McGraw Hill. 586-93.

Bradley MA, Thomas RP. 2011. Hematopoietic Agents: Growth Factors, Minerals, and Vitamins. Goodman \& Gilman`s the Pharmacological Basis of Therapeutics. 12th ed. USA; McGraw Hill. Pp. 923.

Joseph T. DiPiro, Robert L. Talbert, Gary C. Yee, Gary R. Matzke, Barbara G. Wells, L. Michael Posey. 2011. Hematologic Disorders-Anemia. Pharmacotherapy: A Pathophysiologic Approach. $8^{\text {th }}$ ed.; USA; McGraw Hill. 1023-47.

Masters SB. 2013. Agents Used in Anemia; hematopoietic Growth Factors. Katzung BG`s Basic \& Clinical Pharmacology. $12^{\text {th }}$ International edition; McGraw Hill Lange. 581-659.

Mason, Rivers, Helwig. Recent trends in malnutrition in developing regions: Vitamin A deficiencies, anemia, iodine deficiency, and child underweight. Food and Nutrition Bulletin, 2005; 26: 57-162.
Miyashita K, Tojo A, Kimura K. 2011. Iron Deficiency and Other Hypoproliferative Anemias. Harrison's Principles of Internal Medicine. 18th International Edition: McGraw Hill. Pp. 586-93.

Faich G, Strobos J. Sodium ferric gluconate complex in sucrose: Safer intravenous iron therapy than iron dextrans. Am J Kidney Dis, 1999; $33: 464-70$.

Kiran KV, Guru PB, Srinivasa RK, Manavalan R, Manna PK, Mohanta GP, Lavanya KK. Study of Effect of Intravenous Iron Sucrose in the Treatment of Puerperal Anemia. Indian Journal of Pharmacy Practice 2010 (12); 3 (4): 14-7.

Megha. Stability of ferrous ascorbate and its significance for iron absorption. [ONLINE] Available on: www.pharmatile.com/2012/03/ stability-of-ferrous-ascorbate-and-its-significance-for-iron-absorption/ [Accessed 07 March 2012].

Khaldoun Khamaiseh, Yousef Tahat, Ziad Shreideh, Fatima Quran. Intravenous Iron Sucrose vs. Blood Transfusion in the Management of Symptomatic Post Partum Iron Deficiency Anaemia. JRMS March 2011; 18(1): 15-19.

Suheyl Asma, Can Boga, Hakan Ozdogu. Safety, therapeutic effectiveness, and cost of parenteral iron therapy. Int J Hematol, 2009 90:24-7.

Mircescu G, Ga^ rneat $\mathrm{a}^{\swarrow} \mathrm{L}, \mathrm{Ca}^{\circ}$ pusa ${ }^{-} \mathrm{C}$, Ursea N. Intravenous iron supplementation for the treatment of anaemia in pre-dialyzed chronic renal failure patients. Nephrol Dial Transplant, 2006; 21: 120-24.

Tokars ML. Comparison of safety and Efficacy of Intravenous Iron Versus Oral Iron in Chronic Renal Failure Subjects with Anemia. Luitpoid Pharmaceuticals. [ONLINE] Available on: www.clinicaltrials.gov/ct2/show/NCT00236977 [Accessed 07 October 2010]

Stoves J, Inglis $\mathrm{H}$ and Newstead CG. A randomized study of oral vs. intravenous iron supplementation on patients with progressive renal insufficiency treated with erythropoietin. Nephrol Dial Transplant. 2001; 16: 967-74.

Rang HP, Dale MM, Ritter JM, Flower RJ and Henderson G. 2011. Hematopoietic system \& treatment of anemia. Rang and Dale`s Pharmacology. $7^{\text {th }}$ International edition; ELSEVIER Churchill Livingstone. Pp. 309-19.

\section{How to cite this article:}

Pavan Jagdishbhai Panchal, Mira Kiranbhai Desai, Samidh P Shah, Manish N Solanki. Evaluation of Efficacy, Safety and Cost of Oral and Parenteral Iron Preparations in Patients with Iron deficiency Anemia. J App Pharm Sci, 2015; 5 (03): 066-072. 